\title{
Unsafe River Bank Houses? A Context of Human Rights Issues on Freedom from Poverty, Development Programmes, and Accountability Mechanisms in Indonesia
}

\author{
Erna Dyah Kusumawati, University of Groningen, The Netherlands
}

\begin{abstract}
Worldwide, millions of the most deprived people live in slums with a lack of access to adequate water, hygiene, and sanitation. Inadequate housing and living conditions increase vulnerability to other problems. For example, people living on the river banks in Jakarta, Indonesia regularly experience flooding due to adverse environmental conditions. Not only do river bank settlements suffer from floods but also other settlements as well as offices in Jakarta encounter similar effects. These regular floods cost billions of Indonesian Rupiahs (IDR) in damages annually. As part of flood prevention programmes, the Jakarta government evacuated and emptied the river bank settlements and relocated the residents to rented, public high-rise housing provided by the municipality. This article will not address the legal issues of the relocation. Rather, it will examine whether relocation and resettlement due to development programmes can be addressed from a different perspective, one which focuses on human rights as a means to eliminate poverty. This research will also investigate the available accountability mechanisms at both the international and national level. Furthermore, these mechanisms are assessed to determine whether they can be employed to address the effect of development programmes which disproportionally affect people living on river banks. This study uses the classic legal research method, i.e. the normative legal method, to answer the research questions. In addition, the human rights-based approach is employed in assessing the regulation and policies adopted by the Indonesian authorities. The final part of this article provides conclusions and recommendations for policymakers to address the societal problems by employing the human rights approach in tackling poverty and reducing the negative impacts of developments.
\end{abstract}

Keywords: River Banks Settlements, Freedom From Poverty, Development, Human Rights, Accountability Mechanisms, Indonesia

\section{INTRODUCTION}

Article $28 \mathrm{H}$ (1) of the Indonesian Constitution 1945 stipulates that Indonesian citizens are entitled to the rights to live in physical and spiritual prosperity, to have a home, to enjoy a good and healthy environment, and to have access to medical 
care. ${ }^{1}$ In addition to the Constitution, the Indonesian Human Rights Law No. 39/1999 also protects the rights to housing, as specified in Article 40, which recognises the right to a place to live and the right to a decent life. The Indonesian government also ratified several international treaties highlighting the right to housing. ${ }^{2}$ These treaties indicate that the government is under the obligation to realise the right to housing of its people. Therefore, the Indonesian government has also committed to fulfilling the right to adequate housing and to address discrimination in access to housing. The commitment is mentioned in the National Long-Term Development Plan 2005-2025 (RPJPN) and the National Medium-Term Development Plan (2010-2014) (RPJMN). ${ }^{3}$

However, due to massive urbanisation and the population explosion, which is predicted to reach 270 million people by the end of $2020,{ }^{4}$ poverty has severely hit Indonesia; 28.6 million people still live below the poverty line. Land and houses are becoming unaffordable; this has resulted in an unavoidable situation in which a large number of people do not have access to adequate housing. They

1 The 1945 Constitution of the Republic of Indonesia. This article was adopted in the Constitution on the second amendment in 2001. All the translation of national legislations is belong to the author.

2 Indonesia is a party of the most prominent international treaty that served as a legal basis in the recognition of the right to housing of people, i.e. the International Covenant on Economic, Social and Cultural Rights. Moreover, it is also a state party to thematic of international human rights instruments which also recognise the right to housing, i.e. Convention on the Elimination of all Forms of Discriminations Against Women (CEDAW), Convention on the Rights of the Child (CRC), Convention on the Elimination of All forms of Racial Discrimination (CERD), Convention Against Torture and Other Cruel, Inhuman and Degrading Treatment or Punishment (CAT) , Convention on the Protection of the Rights of All Migrant Workers and Members of Their Families (ICMW) , Convention on the Rights of People with Disabilities.

3 The "Rencana Pembangunan Jangka Panjang Nasional 2005-2025" is enshrined in the Law No. 17 /2007. It affirms that there is a need to develop housing due to the rapid increase of the population and in 2020, the housing need will exceed 30 million units in order to house people who do not stay in or have a decent housing (see under D. Sarana dan Prasarana, para. 5). Further, it states some challenges which should be tackled e.g. fulfilling the housing need of the citizens and eliminating slums in urban area, by tax reform, requesting private developers to be involved in providing housing etc.

The "Rencana Pembangunan Jangka Menengah" is also stipulated in the Law No. 17/2007, and in 2015 Indonesia commenced the third RPJM which runs until 2019. The focus of this period is to increase the level of welfare of the citizen as well as to enhance the availability of infrastructure which encourages the programme "cities without slums". See details in Law No. 17/2007, IV.2.3 RPJM ke-3 (2015 - 2019) at 66-67.

4 Badan Perencanan Pembangunan Nasional (BAPPENAS), Badan Pusat Statistik (BPS) and United Nations Population Fund (UNFPA), Proyeksi Penduduk Indonesia (Indonesia Population Projection) 2010-2035 (Jakarta, Badan Pusat Statistik, 2013) online: BAPPENAS <https://www.bappenas.go.id/files/5413/9148/4109/Proyeksi_Penduduk_Indonesia_2010-

2035.pdf>; "Explore Data", online: The UN Habitat website $<$ http://urbandata.unhabitat.org/explore-

data/?countries=ID\&indicators=slum_proportion_living_urban,population,urban_population_cit ies>. 
live in poor houses on illegal settlements such as under bridges, on river banks, and on ex-railway tracks. Such settlements are considered illegal and in some cases are dangerous; thus, the residents are vulnerable to forced eviction.

Due to some development programmes, such as city beautification and dam development, cities in Indonesia are actively eradicating slums. Jakarta, for example, has declared its aim to become a slum-free city by 2019. Moreover, Jakarta, a city prone to annual floods, has planned to vacant its riverbanks in order to return them to their original state and function. As almost all riverbanks in Jakarta are full of either permanent or temporary houses, their function to hold water from the river is not retained. For this reason, the Jakarta government planned the clearance of the slums. In 2015 through 2016, the government forcibly evicted 13,800 families and 11,662 microeconomic production units. ${ }^{5}$ Despite the negative effects of such evictions, the government provided alternative accommodation in rented public houses for the evictees. The government claimed that living in rented, public housing will improve the financial situation of the evictees and make their life more human compared with living in slums on river banks.

This article assesses whether relocation and resettlement due to development programmes can be addressed from a different perspective focusing on human rights as a means to eliminate poverty. The available accountability mechanisms are investigated at both an international and national level to hold the government accountable for the negative effects of development which have infringed human rights. Furthermore, these mechanisms are assessed as to whether they can be employed to address the effect of development programmes that disproportionally affect people living on river banks.

In order to provide a clear analysis and explanation, this paper will be structured into three parts. The first section will provide a brief literature review on freedom from poverty, as well as the relation between human rights and development. The second part will address poverty eradication in Indonesia from a legal perspective. This section is crucial in the analysis which investigates whether the resettlement from riverbanks to rented public housing is a beneficial decision for both the people and for the sake of development. The third section focuses on the possible accountability mechanisms in Indonesia that can be employed to settle the issue on human rights caused by development will also be provided.

5 Alldo Fellix Januardy, Julio Castor Achmadi \& Cindy Iqbalini Fortuna, Seperti Puing: Laporan Penggusuran Paksa di Wilayah DKI Jakarta Tahun 2016 (Jakarta, 2017) at 30. 


\section{FREEDOM FROM POVERTY IN THE HUMAN RIGHTS AND DEVELOPMENT ISSUE}

Traditionally, poverty is defined as having a low income. Thus, those with a low income cannot afford the basic necessities. ${ }^{6}$ However, the definition has evolved in a multidimensional field and has many faces. ${ }^{7}$ The poor themselves see poverty as a deprivation of any element of life, for example: education, health, access to essential services, as well as social discrimination. All of these elements relate to the issue of inequality within society as well as a form of deprivation. ${ }^{8}$ According to Amartya Kumar Sen, a Nobel winner in economic sciences, poverty is a type of unfreedom caused by socioeconomic and structural conditions. Sen's various works have been influential for the work of the United Nations Development Bodies in the mainstreaming of the issue of poverty from a human rights and development perspective. ${ }^{9}$

Since the 1990 s, poverty has been seen more than just a personal misfortune yet also as a human rights concern. ${ }^{10}$ The relation between human rights and poverty can be found in the draft guidelines of Human Rights and Poverty Reduction: A Conceptual Framework. ${ }^{11}$ The framework attempts to provide input into poverty reduction strategies basing the analytical relations between rights and poverty i.e. capability poverty, which led to freedoms and unfreedoms. ${ }^{12}$ This discussion then raises to the question of whether freedom from poverty exists in the international human rights law, or is it included in other freedoms or rights.

The relationship between development and poverty cannot be denied, particularly the fact that development may lead to poverty. However, international human rights (IHR) norms do not recognise freedom from poverty. Experts interpret freedom from poverty from the wording of IHR norms, ${ }^{13}$ such as those written in Article 25 Universal Declaration on Human Rights (UDHR). This article

6 See for example a famous study by Seebohm Rowntree in 1901, cited by Amartya Sen, "Concepts of Poverty" in Poverty Famines An Essay Entitlement (Oxford: Oxford University Press, 1983) 1 at 12.

7 UNDP (United Nations Development Programme), Human Development Report, Human Development to Eradicate Poverty (New York: UNDP, 1997).

8 Sen, supra note 6 at 15 .

9 Desmond McNeill \& Asuncion Lera St Clair, "Poverty, Human Rights, and Global Justice: The Response-Ability of Multilateral Organizations" (2011) 8:1 Globalizations 97, online: <http://www.tandfonline.com/doi/abs/10.1080/14747731.2011.544212>.

10 Daniel P L Chong, "NGOs and Freedom from Poverty" in Free from Poverty: NGOs Human Rights Praxis (Pensylvania: Univeristy of Pensylvania Press, 2010) 1.

11 The Office of the United Nations High Commissioner for Human Rights (OHCHR), Human Rights and Poverty Reduction: A Conceptual Framework, (Geneva, New York: United Nations, 2004) online: OHCHR < https://www.ohchr.org/Documents/Publications/PovertyReductionen.pdf>.

12 McNeill \& St. Clair, supra note 9, at 103-104.

13 Chong, supra note 10 at 6. 
states "everyone has the right to a standard of living adequate for the health and well-being of himself and of his family, including food, clothing, housing and medical care and necessary social services." 14 The article is further supported by Article 11 International Economic, Social and Cultural Rights (ICESCR) stating that,

"[...] recognise the right of everyone to an adequate standard of living for himself and his family, including adequate food, clothing and housing, and to the continuous improvement of living conditions [...]."15

In addition, ICESCR also recognises the right of everyone to be free from hunger. ${ }^{16}$ The similar wording can also be found in other human rights instruments. All of these rights are considered as subsistence rights ${ }^{17}$ - the most basic human rights of which the fulfilment of these rights will influence the enjoyment of other rights, including civil and political rights. ${ }^{18}$ For example, people cannot exercise their right to vote or participate in government affairs if they were deprived of minimum livelihood.

Although there is no freedom from poverty as such, the UN bodies have recognised the relationship between poverty and human rights. Poverty limits human freedoms and human dignity. ${ }^{19}$ Poverty has also been seen as the most complex social phenomenon that assaults human rights. ${ }^{20}$ The adverse impacts of poverty have severely hit the poorest people around the world. The UN considered that significant measures to reduce poverty should be taken and become the priority so that people can be free from poverty, and thus can enjoy the most of their lives. It is crucial that, in order to create a world free from poverty, a charity-based approach cannot be used anymore. The measures should promote the human rights-based approach, which treats the poor as the subjects of development and not objects.

14 Universal Declaration on Human Rights (adopted on 10 December 1948) UN Doc: GA Res. 217 A $\quad$ (III) online: $\quad$ OHCHR <https://www.ohchr.org/EN/UDHR/Documents/UDHR_Translations/eng.pdf>.

15 International Covenant on Economic, Social and Cultural Rights (adopted on 16 December 1966, entered into force 3 January 1976) 993 UNTS (ICESCR), art 11 (1).

16 Ibid art $11(2)$.

17 Ran Hirschl, "" Negative " Rights vs . " Positive " Entitlements : A Comparative Study of Judicial Interpretations of Rights in an Emerging Neo-Liberal Economic Order" (2000) 22:4 Hum Rights Q 1060, online: 〈http://www.jstor.org/stable/4489315>.

18 Henry Shue, Basic Rights: Subsistence, Affluence, and U.S. Foreign Policy, $2^{\text {nd }}$ ed (Princeton: Princeton University Press, 1996) at 5 \& 19.

19 United Nations Development Program (UNDP), Human Development Report 2000: Human Rights and Human Development, (New York: Oxford University Press \& UNDP, 2000) at 73.

20 OHCHR, Human Rights Dimension of Poverty, online: OHCHR <https://www.ohchr.org/EN/Issues/Poverty/DimensionOfPoverty/Pages/Index.aspx>. 
With the massive development agenda, the adverse impact of development is unavoidable. There might be circumstances in which development projects may bring consequences which causes the poor to become poorer and extreme poverty to be increased. Such circumstances include the loss of indigenous land due to massive plantations or mining areas which have made indigenous people lose their resources. ${ }^{21}$ This condition triggered a debate on the issue that, morally, poverty is a form of human rights violation. ${ }^{22}$ However, such a claim still lacks conceptual clarity. ${ }^{23}$ Although there are some measures and documents adopted by the UN bodies, they do not act as supporting evidence for poverty to be considered as a human rights violation. In addition, up until now, there are no legally binding documents supporting the claim. While there is a strong relationship between poverty and human rights, experts agree that poverty is a human rights issue and not a human rights violation in a legal sense. However, poverty may be categorised as a human rights violation upon fulfilling certain requirements, such as if there is a persistent condition when the government fails to addressing poverty by using its maximum available resources. ${ }^{24}$

Rather, this article poses the argument that violations can be both a cause and a consequence of poverty. ${ }^{25}$ In this approach, poverty is seen as a factual situation which may trigger or be the result of a violation. The UN documents do not mention poverty as a violation of human rights rather "a violation of human dignity" ${ }^{26}$ inhibiting "the full and effective enjoyment of human rights." ${ }^{27}$ This wording is intentionally chosen given the fact that states are reluctant to accept legal responsibility with regard to poverty. ${ }^{28}$

21 Kevin Alan David Macdonald, "Indigenous peoples and development goals: A global snapshot" in Gillette H Hall \& Harry Anthony Patrinos, eds, Indigenous Peoples, Poverty, and Development (Cambridge: Cambridge University Press, 2012) 17.

22 Thomas Pogge, "Severe Poverty as a Human Rights Violation" in Thomas Pogge, ed, Free from Poverty as a Human Right who owes what to very poor? (Oxford: UNESCO and Oxford University Press, 2007) 11; see also Tom Campbell, " Poverty as a Violation of Human Rights: Inhumanity or Injustice?"in Thomas Pogge, ed, Free from Poverty as a Human Right who owes what to very poor? (Oxford: UNESCO and Oxford University Press, 2007) 54.

23 Fernanda Doz Costa, "Poverty and Human Rights: From Rhetoric to Legal Obligations - A Critical Account of Conceptual Framework" (2008) 9 Sur - Int J Hum Rights 81.

24 Philip Alston, "Ships Passing in the Night: The Current State of the Human Rights and Development Debate seen through the Lens of the Millennium Development Goals" (2005) 27:3 Hum Rights Q $\quad$ Q 255, online: <http://muse.jhu.edu/content/crossref/journals/human_rights_quarterly/v027/27.3alston.html>.

25 Alice Donald \& Elizabeth Mottershaw, Poverty, Inequality and Human Rights: Do Human Rights Make a Difference? (2009) at 12.

26 Vienna Declaration and Programme of Action, adopted by the World Conference on Human Rights on 25 June 1993, UN Doc: A/CONF.157/23, para 25.

27 Ibid para 14.

28 Alston, supra note 24 at 787. 
Poverty likely occurs in situations where human rights are unlikely to be fulfilled; thus, poverty eradication is beneficial to fulfil human rights. ${ }^{29}$ Further, the UN independent expert on extreme poverty stated that "human rights fulfilment is a basis of condition of life without poverty." 30 Although poverty can be alleviated, it does not mean that human rights are not violated. ${ }^{31}$ An example of this can be witnessed in a certain period, for example in the 1990s when the world successfully reduced poverty for example Britain, Japan, and China, ${ }^{32}$ there were still several occurrences of human rights violation.

As development cannot be avoided, states, as duty bearers of human rights, should ensure that a development project does not severely affect the poor. States have to adopt measures to alleviate or to address poverty. Poverty eradication as a social objective plays an instrumental role in achieving other policy objectives, i.e. creating conditions of well-being for the rights holders. ${ }^{33}$

The next section will provide a description and analysis of the measures adopted by Indonesia to eradicate poverty particularly in the form of resettlement programmes. The analysis will be useful to see whether Indonesia aims to mitigate poverty experienced by the poorest living in slums.

\section{RESETTLEMENT PROGRAMME AS A MEANS TO ALLEVIATE POVERTY}

Alleviating poverty is not new to the Indonesian government, who started to adopt several programmes to redressing poverty in the $1990 \mathrm{~s} .{ }^{34}$ Today, poverty reduction has become one of the crucial objectives elaborated in the National Development Planning both in the long term and mid-term.

Starting in the middle of 1997, Indonesia experienced a massive economic and political crisis. It resulted in nearly double the number of people living in poverty, rising from around $17 \%$ to $24 \%$ in the period between 1996 and $1999 .{ }^{35}$ Further research also showed that poverty rates increased by $164 \%$ from the

29 Doz Costa, supra note 23 at 94.

30 United Nations Economic and Social Council (ESC), Report of the Independent Expert on Human rights and Extreme Poverty Arjun Sengupta, UN Doc: E/CN.4/2006/43; 2 March 2006, para 41 .

31 Ibid

32 "Fewer, but still with us, The world has made great progress in eradicating extreme poverty", The Economist (30 March 2017) online: The Economist <www.theeconomist.com>, see also Chong, supra note 11 at 8.

33 ESC, supra note 30 section II.

34 Asep Suryahadi et al, Review of Government's Poverty Reduction Strategies, Policies, and Programs in Indonesia (Jakarta, 2010) at 3.

35 Badan Pusat Statistik, Dasar-dasar Analisis Kemiskinan (Jakarta, Indonesian Statistic Agency and World Bank Institute, Jakarta, 2002). 
beginning to the end of the crisis at the end of the year1998. ${ }^{36}$ The crisis also caused the number of poor people living in urban areas to double and the rural poor to increase by $75 \% .{ }^{37}$ With all its measures, Indonesia significantly reduced urban poverty levels from $48 \%$ in 1990 to $13 \%$ in $2010 .{ }^{38}$ Until 2017 , the Indonesian poverty rate was still at $10.12 \% .{ }^{39}$

Regarding urban poverty, several strategies have been adopted to tackle urban poverty including the highly successful Kampung Improvement Program (KIP) which was conducted between 1969 and 1999. This programme targeted basic, physical infrastructure such as water supply, sanitation systems, footpaths, drainage, and public amenities such as open space, street lighting, and health clinics. ${ }^{40} \mathrm{KIP}$ resulted in a major drive to improve kampung living conditions. ${ }^{41}$ Another programme that was adopted to reduce urban poverty was the P2KP Program Pengentasan Kemiskinan Perkotaan (Urban Poverty Alleviation Program). ${ }^{42}$ P2KP addressed housing programmes by promoting informal and community-based housing. ${ }^{43}$ This programme united livelihood improvement with social, economic and physical enhancements. ${ }^{44}$

In the current RPJMN (2014-2019), the government prioritises the development of housing and settlements for poor households within the $40 \%$ lowest income range. The government also aims to eradicate slums by 2019. To support this aim, the governments (both national and local) prioritise upgrading kampung and slums through development and management schemes. The schemes include the provision of mortgage facilities for low-income households, integration of housing with social-net support facilities, community-based in-situ slum upgrading programmes, and the building of terraced houses such as

36 Asep Suryahadi, Gracia Hadiwidjaja \& Sudarno Sumarto, "Economic Growth and Poverty Reduction in Indonesia Before and After the Asian Financial Crisis" (2012) 48:2 Bull Indones Econ Stud 209 at 216.

37 Ibid.

38 Paul Jones, "Formalizing the informal: Understanding the position of informal settlements and slums in sustainable urbanization policies and strategies in Bandung, Indonesia” (2017) 9:8 Sustainability 1 at 11 .

39 "Indonesia to strive for poverty rate below 10 percent", Jakarta Post (4 January 2018) online: The Jakarta Post < http://www.thejakartapost.com>.

40 Devisari Tunas \& Andrea Peresthu, "The self-help housing in Indonesia: The only option for the poor?" (2010) 34:3 Habitat Int 315 at , online: <http://dx.doi.org/10.1016/j.habitatint.2009.11.007>.

41 Gustaaf Reerink \& Jean Louis van Gelder, "Land Titling, Perceived Tenure Security, and Housing Consolidation in the Kampongs of Bandung, Indonesia" (2010) 34:1 Habitat Int 78, online: 〈http://dx.doi.org/10.1016/j.habitatint.2009.07.002>.

42 Presidential Regulation 7/2005 on Rencana Pembangunan Jangka Menengah Nasional (the National Medium-Term Development Plan) 2004-2009.

43 Jones, supra note 39.

44 John Minnery et al, "Slum upgrading and urban governance: Case studies in three South East Asian cities" (2013) 39 Habitat Int 162 at 164, online: <http://dx.doi.org/10.1016/j.habitatint.2012.12.002>. 
attached apartments, both low or high rise. The national government and local governments work collaboratively to achieve these results. Local authorities mostly implement the policy laid down by the national government. ${ }^{45}$

In conducting the slum upgrading programmes as one of its measures in eradicating slums, the national government seems to be avoiding eviction and will provide compensation in the form of land, cash, and economic activities, especially in the case of the development of flood mitigation systems or highways. ${ }^{46}$ However, forced evictions in the name of development of public interest have occurred, in which around 14,000 families were evicted in 2015$2016,{ }^{47}$ and no or little compensation was given to people affected. Instead of insitu upgrading, the affected communities were forced to resettle in rented public housing.

Poor people living in slums are vulnerable to eviction. The reasons for such removal varies. For example, in Jakarta, the government planned to reinstate the original function of the river, namely to hold the rainwater so that the rivers stabilisation will prevent flooding in the future. ${ }^{48}$ Correspondingly, the Jakarta government wished to build a dam as well as a large wall to protect the city from sinking and to prevent seawater from entering the city. Such projects also affect other cities including Surabaya and Surakarta, with similar reasons, yet they relate more to law enforcement in terms of planning law that stipulates riverbanks should be free from permanent buildings. ${ }^{49}$ Moreover, the governments are of the opinion that riverbank settlements are unsafe and inadequate. Therefore, by staying in public housing, people's living conditions will be significantly improved, especially considering that the residences will be more decent. Resettlement also has another effect which will eliminate slums. Compared to riverbanks, which are prone to annual flooding, the location of public housing is less prone to flooding. As annual flooding causes severe losses, which further affect the inhabitants' financial situation, ${ }^{50}$ leaving riverbanks may potentially provide an opportunity to improve their finances.

45 Erna Dyah Kusumawati, The Recurring Dream of Affordable Housing in Indonesia: A Human Rights Perspective in Michel Vols \& Sidoli, J. (eds.), People and Buildings: Comparative Housing Law. Studies in Housing law Vol. 2 (The Hague: Eleven International Publisher) 105140; see also Erna Dyah Kusumawati, Antenor H. De wolf \& M.M.T.A. Brus, "Access to Public Housing for Outsiders; a Practice of Indirect Discrimination in Decentralised Indonesia" (Forthcoming) APJHRL.

46 Jones, supra note 39.

47 See Fellix Januardy, Castor Achmadi \& Iqbalini Fortuna, supra note 6.

48 Human Rights Watch (HRW), Condemned Communities Forced Evictions, Vol 18 No. 10C (Jakarta: HRW, 2006) online: HRW < Human Rights Watch, "Condemned Communities Forced Evictions>.

49 Ashok Das, "A City of Two Tales: Shelter and Migrants Surabaya" (2017) 8:1 Environtment Urban Asia 1.

50 Roanne Van Voorst, “Applying the Risk Society Thesis within the Context of Flood Risk and Poverty in Jakarta, Indonesia” (2015) 17:3-4 Heal Risk Soc 246 at 252. 
By resettling people from slums and illegal settlements, the government succeeded in fulfilling several targets in once, such as cleaning up cities from slums, building infrastructure to protect cities from disaster, and rescuing people from poverty by providing better and decent housing.

In several major Indonesian cities, local governments have cleaned their riverbanks and resettled the inhabitants into rented, multi-storey public housing. However, the people cannot permanently stay in the public housing as the government regulates the period of stay, which is mostly capped at two years for an initial stay. This time limit can be extended a maximum of three times. ${ }^{51}$ The period of stay varies from city to city and depends on the local governments' policy. The governments are of the opinion that, in the time when people reside in the rented and subsidised public housing, they can save money and later move to their own home. ${ }^{52}$

Moreover, as a part of urban renewal strategies, the development of rented multi-storey housing aims to improve the quality of life for people living in informal settlements. ${ }^{53}$ Moreover, rented public housing is one of the strategies utilised to tackle the problem of land availability in big cities and to improve the security of tenure of low-income groups that cannot afford to buy a house. ${ }^{54}$

However, not all people affected by the development programmes accepted the alternative accommodation provided by the government. For example, in 2016, many of the evictees from Pasar Ikan refused the offer, citing that the public housing is far from their workplace and does not provide security of tenure. ${ }^{55}$ In addition, there was an insufficient number of public housing units compared to the number of people evicted. Furthermore, only people holding a Jakarta Residence card could receive alternative accommodation and those who did not have one could not stay in the public housing. ${ }^{56}$

For those who accepted to stay in the new accommodation with a relatively cheap rental fee had to adapt to the new living environment. The government

51 Fellix Januardy, Castor Achmadi \& Iqbalini Fortuna, supra note 6; see also for example Governor Regulation of DKI Jakarta No. 111/2014 on Mekanisme Penghunian Rumah Susun Sederhana Sewa (Renting Mechanism of the Rented Public Housing); Local Regulation of Kota Surabaya No. 2/2010 on Pemakaian Rumah Susun (The Usage of Multi-storey Housing); Mayor Regulation of Yogyakarta No. 44/2009 on Pengelolaan Rumah Susun Sederhana Sewa Milik Pemerintah Kota Yogyakarta (the Management of Rented Multi-storey Housing owned by the Jogjakarta Municipality).

52 Interview with local officials of Jakarta, Surabaya and Solo, in file at the author in Indonesian language.

53 Direktorat Jenderal Cipta Karya, Rusunawa: Komitmen Bersama Penanganan Pemukiman Kumuh, Kementerian Pekerjaan Umum (Jakarta, 2012) 21-22, online: Dirjen Cipta Karya <http://ciptakarya.pu.go.id/bangkim/old_file/v2/download/ebook/Buku_Rusunawa_2012.pdf?ifra me $=$ true\&width $=1400 \&$ height $=650$.> .

54 Ibid.

55 Erna Dyah Kusumawati, "Between Public and Communal Interests: a Legality Issue of Forced Evictions Occurring in Jakarta” (2018) 8:1 Indones Law Rev 87 at 99.

56 Ibid. 
also provided a means of transportation for children to go to school every day for free. Moreover, the government also furnished the housing units. With all the government's efforts in providing alternative accommodation, the question may arise of whether moving to multi-storey housing improves the inhabitants' financial situation and therefore alleviating them from poverty.

One cannot deny that the public housing is more decent, more modern, and cleaner. Particularly in Jakarta, public housing that was designed for the poor people affected by development programmes is fully furnished. In terms of physical conditions, such as sanitation, public spaces, and clean drinking water, public housing is much more adequate than their previous settlements. ${ }^{57}$

However, several problems have been identified by the Jakarta Legal Aid Institute, which researched people's lives in the public housing. The inhabitants mentioned that their economic condition worsened due to the decrease in income and they still needed to pay the monthly rent. ${ }^{58}$ This is understandable as many of the evictees have their warung (small scale grocery shop or food stall) as a source of income. However, in some of the public housing, it is not possible anymore to open such economic activities. If it is possible, the inhabitants need to pay extra to rent the stall units. ${ }^{59}$ The additional payment for the economic units burden the tenants.

Although the more adverse effects of the resettlement need to be further investigated, several adverse impacts of new settlements for the evictees have been revealed. Because of the economic drawbacks, many inhabitants cannot pay their rent. $^{60}$ The frequent rent-arrears can bring further consequences, namely they may have to leave their home, or they cannot extend the rental agreement. The regularity of the rental payment is decisive in extending their stay. ${ }^{61}$ If they cannot pay, then they will be evicted, and they will be homeless. As they cannot afford another house, they might end up renting cheap and inadequate rooms or build permanent houses elsewhere. If no measures are adopted to prevent this from continuously occurring, more people will end up in slums. Ultimately, it is a never-ending set of circumstances and it is becoming a pressing issue.

57 See Nuri Ikawati et al, Penggusuran dan Reproduksi Kemiskinan Kota: Studi Kasus di Empat Rusunawa Jakarta (Jakarta, 2017) 22-25.

58 Alldo Fellix Januardy et al, Mereka yang Terasing: Laporan Pemenuhan Hak atas Perumahan yang Layak bagi Korban Penggusuran Paksa Jakarta yang Menghuni Rumah Susun (Jakarta: Lembaga Bantuan Hukum Jakarta, 2016) at 45-49.

59 Ikawati et al, supra note 58, at 25.

60 Fellix Januardy et al, supra note 59.; see also Tiara Sutari, "Warga Rusun Akui Tunggak Sewa Karena Kesulitan Ekonomi”, CNN Indonesia (6 September 2017) online: CNN Indonesia <https://www.cnnindonesia.com>; Robertus Belasminus, "Warga Kampung Pulo yang Direlokasi ke Rusun Kesulitan Bayar Sewa", Kompas (31 March 2016) online: Kompas <https://megapolitan.kompas.com>.

61 This requirement exists in rental housing regulation adopted by local governments, such as Jakarta, Surabaya, Yogyakarta, and Surakarta. 
Based on several weaknesses and challenges found in the resettlement programme, it is crucial to assess that the resettlement programme to public housing will help to eradicate poverty or will lead to further poverty. To examine the programme, the human rights-based approach will be employed and will be provided in the next section.

\section{RESETTLEMENT TO PUBLIC RENTED HOUSING AS A RESULT OF DEVELOPMENT PROJECTS LEADS TO POVERTY ALLEVIATION: THE NEED OF A HUMAN RIGHTS-BASED APPROACH (HRBA)}

The previous section had discussed several weaknesses that can be found in the resettlement programmes, namely: (1) limited time to stay in public housing security of tenure; (2) insufficient number of housing, (3) limited access to public housing only for local residents, (4) loss of jobs, (5) no compensation provided, and (6) uprooted cultural way of life. These indications can trigger the opinion that the resettlement of the people from slums to rented public housing is not a measure to alleviate poverty.

Forced eviction as a result of development can uproot people from their socio-economic situation. One cannot deny the importance of development for a country; however, a development project should fulfil three requirements: it should be ethically acceptable, socially sustainable, and minimally damaging to the environment. ${ }^{62}$ Ethically acceptable means that a project does not serve the interests of particular groups but serves the interests of a great number of people and can be implemented without involving any form of discriminatory practices. ${ }^{63}$ The total elimination of the negative effects of a development project is impossible; nonetheless, responsible parties implementing the project should put in maximum effort to restore the economic conditions of the affected communities, conditions similar to those which existed before the project started. ${ }^{64}$ In the long term, the communities should enjoy the result of development on an equitable basis.

Involuntary relocation or resettlement as a result of eviction in a country characterised by the land-based economy, low employment possibilities, and a strong rooted social stratification, such as Indonesia, could lead to severe consequences. These include the loss of economic activities which might lead to further poverty. The change of the environment from riverbank settlements to multi-storey housing might affect their social bonds within the neighbourhood. This social relation is of substantial value to the people living in slums. The spirit

\footnotetext{
62 Bogumil Terminski, Development-Induces Displacement and Resettlement: Causes, Consequences and Socio Legal Context (Stuttgart: Ibidem, 2015) at 52-53.

63 Ibid at 53.

64 Terminski, supra note 62 at 53.
} 
of togetherness - gotong royong - and helping each other could significantly decrease as the community would be split into different floors or even separated by buildings or blocks.

Currently, no legally binding instrument exists to regulate how the government can relocate or resettle people affected by a development project. In 2007, the UN Special Repertoire on the right to housing introduced a set of basic principles and guidelines on development-based evictions and displacement. ${ }^{65}$ This document emphasises the obligation of states to refrain from forced evictions and to protect their people if such activities occur. ${ }^{66}$ Moreover, in terms of eviction, it highlights the interdependence of civil rights to the non-interference of home and private life with the right to adequate housing. ${ }^{67}$ Development-based evictions should be (1) carried out in accordance with international human rights standards, (2) undertaken solely for the purpose of promoting the general welfare, (3) reasonable and proportional, as well as (4) regulated to ensuring full and fair compensation and rehabilitation. The general welfare, according to the UN Special Repertoire, refers to the urgent need to protect the most vulnerable group in the society.

The guidelines provide measures that should be taken by governments in every phase of eviction, i.e. prior, during, and post-eviction. This article does not discuss the first two phases, yet only concerns the post phase. In this phase, states are obliged to provide fair compensation and sufficient alternative accommodation, or restitution when feasible. The compensation scheme should be carried out in a non-discriminatory manner and should be immediately conducted upon the evictions. ${ }^{68}$ In several cases of evictions, Indonesian local governments did provide alternative accommodation for registered residents, but compensation was rarely granted or, if granted, the amount of compensation was usually less than the market price.

From the human rights perspective, providing alternative accommodation in rented public housing is not sustainable in the long run. Notably, the difficulties that people face in paying rent, as well as the loss of community bonding are evidence of the insufficiency of such a measure. Moreover, as the alternative accommodation was only given to local residents, poor migrants from other cities had no other place in which to stay and were left behind. ${ }^{69}$ These two facts will create further challenges in urban areas.

The HRBA to development in this regard is crucial. The approach is based on international human rights norms; it functions to reduce the adverse effects of

65 United Nations General Assembly, the Basic Principles and Guidelines on Development-Based Evictions and Displacement, UN Doc A/HRC/4/18 (5 February 2007) <https://www.ohchr.org/Documents/Issues/Housing/Guidelines_en.pdf>.

Ibid., para. 1.

67 Ibid., para. 2.

68 For the detailed obligations of states after eviction see the guidelines, ibid, paras 52-58.

69 Kusumawati, De wolf \& Brus, supra note 45. 
development on people. ${ }^{70}$ The approach emphasises not only the process of the development but also the outcome by focusing more on people's living conditions, their needs, problems, and potential. ${ }^{71}$

The HRBA contains four principles: (1) participation and consultation of those affected and beneficiaries (empowerment), (2) non-discrimination, and (3) special attention to the needs of vulnerable and marginalised subgroups, and (4) accountability. ${ }^{72}$ The first three principles are needed due to the shift of the development as a charity-based or needs-based approach into a rights-based approach that emphasises the realisation of rights and empowerment. ${ }^{73}$ This shift ensures that citizens play a role in the development rather than simply being the object of development.

There is nothing wrong with providing public housing for people affected by development programmes, particularly if the design of public housing aims to tackle the problem of land availability that occurs in many major cities. However, the resettlement plan should be promoted to the affected community so that they can participate in the decision-making process. The people claimed that the relocation plan was never communicated. ${ }^{74}$ They knew that the eviction would be taking place, but they did not know about the location of the resettlement. People at a later stage were not involved in deciding which public housing they will be resettled to; instead, the government provided them with a fixed place and no other choice could have been taken.

Moreover, right to housing does not only concern with the adequacy and modernity of the building, but it also concerns with cultural identity and diversity of housing. ${ }^{75}$ Therefore, the development of new settlements should take into

70 Siddiq R Osmani, "The human rights-based approach to development in the era of globalization" (2004) Right to Dev 117, online: OHCHR <http://www.ohchr.org/Documents/Issues/Development/RTDBook/PartIIChapter8.pdf>.

71 Wouter Vandenhole \& Paul Gready, "Failures and Successes of Human Rights-Based Approaches to Development: Towards a Change Perspective" (2014) 32:4 Nord J Hum Rights 291, online: <http://www.tandfonline.com/doi/abs/10.1080/18918131.2015.957458> 293; Rory Hearne \& Padraic Kenna, "Using the Human Rights Based Approach" to Tackle Housing Deprivation in an Irish Urban Housing Estate" (2014) 6:1 J Hum Rights Pract 1, online: $<$ https://academic-oup-com.proxy-ub.rug.nl/jhrp/searchresults?rg_IssuePublicationDate=01\%2F01\%2F2014+TO+12\%2F31\%2F2014\&fd_Volume=6\&fd_Is sueNo=1\&fd_StartPage=1> ; Lidewij van der Ploeg \& Frank Vanclay, "A human rights based approach to project induced displacement and resettlement” (2017) 35:1 Impact Assess Proj Apprais 34, online: <https://www.tandfonline.com/doi/full/10.1080/14615517.2016.1271538> 38. Vandenhole \& Gready, ibid, at 294; Hearne \& Kenna, ibid.

73 Urban Jonsson, Human Rights Approach to Development Programming (UNICEF, 2003) 21.

74 Vera W Soemarwi, Handika Febrian \& Kristian Feran, Politik Hukum Rusunawa dalam Penggusuran Paksa Warga Bukit Duri: Studi Kasus Rusunawa Rawa Bebek (Jakarta: Yayasan Ciliwung Merdeka, 2017).

75 UN Committee on Economic, Social and Cultural Rights (CESCR), General Comment No. 4: The Right to Adequate Housing (Art. 11 (1) of the Covenant), 13 December 1991, E/1992/23 para $8(g)$. 
account the cultural adequacy of the affected community. Based on this norm, the design of public housing should reflect the communal life of society, ${ }^{76}$ which can be done by providing more public spaces in public housing. In this case, the evictees were forced to move to multi-storey housing which was new for them. They used to live in a row and close to each other in the neighbourhood where they can talk and do social activities together. In the new building, they live in a multi-storey housing, one neighbourhood is rarely to be on the same floor. This was possible because the governments used a lottery system in distributing the housing units. Therefore, one may wonder if people may end up living with strangers coming from different areas as a result of development programmes occurring in such areas. This arrangement will affect the communal value possessed by the people. This issue could be avoided if the government involved the people in designing the new place and in distributing the housing units.

Furthermore, a resettlement policy should not be discriminatory in any nature. In addition, based on the HRBA, a policy should give special attention to most vulnerable groups in the society. As discussed in the previous section that the local regulations only allow people with a local resident card to stay in the public housing provided for the evictees, this policy might disadvantage a certain group of people. While not all the evictees are local residents, there is a group of people who cannot access the alternative housing. Poor, internal migrants that could not access the alternative accommodation fall under this category. ${ }^{77}$ They were left with no other solution. The governments should also have provided an alternative solution for them; otherwise, they would not be able to afford a place to live and would resort to building temporary houses on abandoned land which in turn would develop further slums in urban areas.

Another drawback of the resettlement is the worsening of the economic condition of the inhabitants of the public housing due to the loss of economic activities from the previous places. For this group, the local government created several educational programmes such as sewing courses or recycling home garbage. The programmes aimed to provide people with knowledge that can be used as an opportunity to increase their income. Such assistance would also enable the government in alleviating poverty as people will make more effort by themselves and will not depend entirely on government subsidies. However, the success of such programmes can only be seen in the long run. While in the short term, people also need help to cover their expenses in their new place. The government should have thought about a solution. Although the government had subsidised the housing at an extremely cheap price, it might also help to provide a soft loan for those who are really in need. For example, a loan for the first six month stay could be granted to enable them to survive. Another option would be to provide free stay for a couple months for evictees, in order to render sufficient

76 Kusumawati, supra note 56.

77 Kusumawati, supra note 45. 
time for the affected communities to restore their financial situation following the eviction. It is the task of the government to make sure that the credit or assistance targets and delivers to the right person.

Moreover, the difficulty people face when paying rent should also be considered. The time limit to stay in the public housing should be extended, given the fact that people experience economic difficulties when adapting to a new environment. An extension of six years, that is two years extended three times, will not provide enough time for certain groups to leave the housing and find an alternative on the market. Therefore, the termination of the rental housing agreement should be handled case by case, taking into consideration the people's economic situation.

The HRBA will not be a panacea to cure the adverse impacts of the evictions and resettlement programmes. However, implementing and incorporating the HRBA principles in all government's policies ${ }^{78}$ would lead to better results and considerably reduce the negative effects of development. ${ }^{79}$ From this discussion, the resettlement into rented public housing cannot be considered as an effort to alleviate poverty itself. These actions might lead to a worsened state of poverty if the policy is not followed by a further strategy employing the HRBA.

The HRBA also contains the accountability principle which relates to the obligation of states, as they are the duty bearers of human rights. Under the human rights regime, states are accountable for their actions in fulfilling their obligations to citizens, as human rights holders. The HRBA can be employed to increase the ability of responsible parties to recognise and know how to respect human rights, to fulfil human rights, and to ensure that parties can be held accountable. The following section will discuss accountability of mechanisms available in Indonesia that can be employed by the people if a development programme infringes and affects their human rights.

\section{LEGAL AND ADMINISTRATICE ACCOUNTABILITY MECHANISMS FOR PEOPLE AFFECTED BY DEVELOPMENT PROGRAMMES}

Accountability is believed to be one of the vital elements in advancing the good governance of a state. Accountability is crucial for governance because evaluating the on-going effectiveness of a policy that has been adopted through the

78 Vandenhole \& Gready, supra note 72.

79 OHCHR, Frequently Asked Questions on a Human Rights-Based Approach to Development Cooperation, HR/PUB/06/8, 2006, at 16-18, online: OHCHR <http://www.ohchr.org/Documents/Publications/FAQen.pdf_; see also Vandenhole \& Gready, supra note 71, at 296 . 
accountability process will encourage officials to perform better when enhancing public services and to be responsive to the society.

The essential meaning of accountability is a mechanism in which actors are obliged to explain and justify their conduct through institutional relations ${ }^{81}$ or arrangements, whereby they might face "consequences." 82 Actors can be either individual, e.g. officials, or an organisation, such as a public institution. To be accountable, an actor should be able to clarify and vindicate its policy before a forum that can also be an individual or an institution. The forum, then, can query the explanations and deliver findings. The relationship between the actor and the forum can be either principal-agent relationships or other types. Based on the relationship, the accountability mechanism of the superior and its representatives can often be found in the internal accountability, whereby the representatives should justify its mandate to its superiors in the same organisation. The nonprincipal-agent relation can frequently be discovered in the arrangement of external accountability, such as courts, ombudsmen, or professional organisations. The establishment of accountability mechanisms is regulated differently in every state and it depends on the national legislation of each country. Principles of accountability and its mechanisms are often provided in constitutions and other domestic regulations.

Helen Potts proposes the notion of accountability by underscoring the urgency of accountability as a process in the area of the right to health. ${ }^{83}$ Within this process, states should provide remedies for people whose rights were violated. As a process, accountability works in a continuous circle, starting from the decision-making policy, incorporation, and implementation of the decision, to the continuously monitoring processes, both by internal and external monitoring institutions. Following the monitoring, accountability mechanisms are needed to serve as a forum for explanation and justification. Ultimately, the need to adopt the provision of remedies or redress is if a violation has occurred. ${ }^{84}$ The notion of

80 Rick Stapenhurst and Mitchell O’Brien, Accountability in Governance, online: World Bank Publication <http://siteresources.worldbank.org>.

81 In addition to Bovens, other scholars such as are Patricia Day and Rudolf Klein adopt this definition that sees accountability as "a relationship between an actor and a forum". See in Mark Bovens, "Analysing and Assessing Accountability: A Conceptual Framework" (2007) 13:4 Eur Law J 447 450, online: <http://doi.wiley.com/10.1111/j.1468-0386.2007.00378.x>, Patricia Day and Rudolf Klein, Accountabilities: Five Public Services (London: Tavistock Publications, 1987) at 4-5.

82 Mark Bovens, "Two concepts of accountability: Accountability as a virtue and as a Mechanism" (2010) 33:5 West Eur Polit 946.

83 Hellen Potts, "Accountability and the Right to Highest Attainable Standard of Health" in Paul Hunt and Tony Gray, eds, Maternal Morality, Human Rights and Accountability (New York: Routledge, 2013) 121 at 122-123; Helen Potts, Accountability and the Right to the Highest Attainable Standard of Health. (Essex, 2007) 13, online: University of Essex 84 <http://repository.essex.ac.uk/9717/1/accountability-right-highest-attainable-standard-health.pdf>. Ibid. 
emphasising the accountability as a process also comprises accountability as a mechanism. Hence, in this article, accountability will be defined as a continuous process involving governments, civil society, institutions/forums, and individuals in order to achieve the protection of human rights, particularly the right to housing and the right to be free from arbitrary eviction. Potts proposes four elements that can boost accountability as a process: monitoring, mechanisms, remedies, and participation. ${ }^{85}$

Under the Indonesian system, the boom of accountability under the good governance principles started after the collapse of the New Order under President Suharto's regime in 1999. Accountability is recognised under the law No. 28 /1999 on the Implementation of a Clean; and Corruption-, Collusion-, and NepotismFree Government. As principles, accountability along with the other six values: principles of legal certainty, public order state administration, public interest, transparency, and proportionality and professionalism, become the spirit of the government institutions to provide reasonable public services. ${ }^{86}$ Accountability serves as a principle that determines that all activities and results of the state administration should be accountable to the people as the holder of the highest sovereignty.

Accountability is a form of responsibility held by mandated parties to the parties which give the mandate. ${ }^{87}$ Further, Budiharjo mentioned that accountability creates a supervisory function through the distribution of powers in numerous government institutions. The distribution aims to reduce the accumulation of power and create the checks and balances system. According to Budiharjo, the parties involved in the accountability process are government institutions, i.e. the executive (the President and the cabinet), the judicative (the Supreme Court and its judicial system), and the legislative (the People's Consultative Assembly and the House Representative); and press and media. The latter holds a significant position in the checks and balances system and it becomes the fourth pillar of the governance system. ${ }^{88}$

This section will not deal with all elements of accountability, however it will deal with the existence of accountability mechanisms under the Indonesian legal system which will be discussed in the following paragraphs.

The accountability mechanism can be pursued through various available mechanisms, from local and national to the international processes. ${ }^{89}$ However,

85 Potts (2013), supra note 83 at 124.

86 Law No. 28/1999 on Penyelenggaraan Negara yang Bersih dan Bebas dari Korupsi, Kolusi dan Nepotisme (Clean Governance and Corruption, Collusions and Nepotism Free) art. 3.

87 Miriam Budiardjo, Menggapai kedaulatan Untuk Rakyat (Bandung: Mizan, 1998) at 107- 120; see also Dra. Loina Lalolo Krina P., Indikator \& Alat Ukur Prinsip Akuntabilitas, Transparansi \& Partisipasi, online: Bakti Digital Library <https://baktilibrary.omeka.net/items/show/83>.

88 Ibid.

89 The international process can be employed by citizens only if states agreed on and ratified the international mechanism provided by certain international instruments. In the case of the 
the international mechanism process is not applicable in Indonesia, particularly in terms of the violation of economic, social, and cultural rights, since Indonesia has not ratified the $2^{\text {nd }}$ optional protocol to the ICESCR. Therefore, Indonesia applies only five types of accountability mechanisms, i.e. judicial, quasi-judicial, administrative, political, and social mechanisms. ${ }^{90}$ The last two types of accountability will not be discussed in this article, as they have been explored by extensive research. For example, studies conducted by the World Bank ${ }^{91}$ and the RTI International (New York) ${ }^{92}$ observed that these two types of accountabilities are also available in the Indonesian legal system.

The judicial mechanisms can be claimed through the General Court-District State Courts (Pengadilan Negeri) which are available in every district/municipality in all Indonesian territories. ${ }^{93}$ People can employ this mechanism to claim their interests through the procedure in this court. They can claim against the government, private parties, or individuals. However, employing such a mechanism generally consumes much time, materials, and energy, without knowing what the result will be. Due to the rampant corruption and collusion in the court system, a large number of people do not trust this institution to settle their conflicts. However, such a mechanism, to a certain extent, is still the only mechanism that provides legal enforcement and remedies or compensates the winning parties. Several cases related to housing have been heard before the court in Surabaya and Jakarta. These cases prove that the society still believes and hopes that the courts can solve their interest and provide them with justice.

Another type of court that can be utilised to challenge government policies is the administrative courts which are located in every municipality. However, not all cases can be heard before this court. This court has a mandate to trial state administrative disputes between individuals or private parties and state institutions or within government's institutions themselves, as a result of an adoption of state administrative decision. ${ }^{94}$ For example, the Jakarta Administrative Court delivered its judgment on $25^{\text {th }}$ April 2015 on the disputes between the DKI Jakarta

International Covenant on Economic, Social and Cultural Rights, states have to ratify the Second Optional Protocol on Individual Complaints concluded on 10 December 2008 under the resolution A/RES/63/117, online: OHCHR <http://www.ohchr.org/Documents/HRBodies/CESCR/OProtocol_en.pdf.

90 Potts (2013), supra note 83 at 125.

91 See for example in Sebastian Eckardt, "Political Accountability, Fiscal Conditions and Local Government Perfomance-Cross-sectional Evidence from Indonesia” (2008) 28:1 Public Adm Dev 1.

92 See for example in Anna Wetterberg, Jana C. Hertz, \& Derick W. Brinkerhoff," Social Accountability in Frontline Service Delivery: Citizen Empowerment and State Response in Four Indonesian Districts" in the International Development Group Working Paper Series (New York: the RTI International, 2015).

93 See Law No 48/2009 on Kekuasaan Kehakiman (Judicial Power).

94 Law 51/2009 on Perubahan kedua Undang Undang No. 5/1986 tentang Pengadilan Tata Usaha Negara (the $2^{\text {nd }}$ Amendment of Law 5/1986 on Administrative Court) art.1 para. 10. 
province and the people living in Bidara Cina. ${ }^{95}$ The Court stated in its merit that there was a mistake made by the government in concluding the decision; therefore, the Court annulled the Government Decree. ${ }^{96}$ As a result of this decision, the government had to temporarily postpone the plan to evict people. The government submitted an appeal to the Supreme Court on $27^{\text {th }}$ April 2016 in which the Supreme Court ruled the opposite judgment of the Jakarta Administrative Court arguing that the absence of the defendant does not mean that the defendant could not prove the accused decree. ${ }^{97}$ Moreover, the pleated appeal did not invoke the claim in a limited time frame; therefore, the claim could not be granted. ${ }^{98}$

Another legal mechanism that can be employed by communities is the Constitutional Court of the Republic of Indonesia. Under the Law No. 8/2011 on the Amendment of Law No. 24/2003 on the Constitutional Court, the Indonesian legal system provides an avenue to challenge the newly adopted laws, especially if they contradict with the Indonesian Constitution or if the constitutional rights of the applicants are violated as a result of the new law. ${ }^{99}$

The second type of accountability mechanism is the quasi-judicial mechanisms. In Indonesia, this mechanism includes two institutions: The National Ombudsman and the Indonesian National Commission for Human Rights (Komisi Nasional Hak Asasi Manusia-KOMNAS HAM). The Ombudsman receives complaints about any dissatisfaction of public services, while KOMNAS HAM accepts and handles complaints on the alleged violations of economic social and cultural rights. ${ }^{100}$ In addition, KOMNAS HAM can also investigate alleged human rights violations; for example, it investigated the possibility of human rights

95 This case registered in the Jakarta Administrative Court with the register number 59/G/2016/PTUN. This case was about the policy adopted by the Governor of the DKI Jakarta in its decision Surat Keputusan Gubernur DKI No. 2779/2015 relating to a plant to build an inlet to reduce the water flow from the main river "Ciliwung." This plan will bring a consequence that is evicting people living in that area (Bidara Cina).

96 Galuh Radiah et al. v. Gubernur Provinsi Daerah Khusus Ibu Kota Jakarta (Jakarta Administrative Court, 25 April 2016, judgment) 59/G/2016/PTUN-JKT online: Mahkamah Agung Republik Indonesia - MARI (The Indonesian Supreme Court) <https://putusan.mahkamahagung.go.id/putusan/c65c8cd899a7de940c022368c0bc965d> paras 144-145, 153.

97 Gubernur Provinsi Daerah Khusus Ibu Kota Jakarta v. Galuh Radiani et al (MARI, 23 August 2016, judgment) $267 \quad$ K/TUN/2016, online: MARI <https://putusan.mahkamahagung.go.id/putusan/c65c8cd899a7de940c022368c0bc965d> paras 34-36.

98 Ibid

99 The other powers that the Court has are delivering judgment on the disputes on authority between state institutions, dissolution of political parties, and the disputes on election results. It also has the authority to give a decision on the opinion of the House of Representatives on alleged violations of laws committed by the President and/or the Chief President (article 10 of the Law No. 24/2003).

${ }^{100}$ Law of 39/1999 on Hak Asasi Manusia (Human Rights) arts. 76, 86 paragraphs 3 and 4. 
violation in a massive eviction case in Jakarta and in the land conflicts in Sumatra. The Ombudsman and KOMNAS HAM, however, can only deliver recommendations, which are not binding to the parties. Therefore, in order to resolve the conflict, the good faith of all parties is indeed crucial.

The internal accountability as a form of administrative accountability is also one vital element to hold officials accountable in the first place. The officials are accountable to their principals; if any of their conducts are against the purpose of their work, the principals have the power to deliver judgment and to impose administrative sanctions. This mechanism exists in every institution in Indonesia because it is obligatory, as encouraged in the Regulation of Menteri Pendayagunaan Aparatur Negara-Permenpan (Ministry of Administrative) ${ }^{101}$ 13/2009 on the Improvement of Quality in Service Delivery with Civic Participation. This regulation legally proposes complaints surveys in order to receive societies' likes and dislikes as well as complaints about public services. The procedure of accountability might vary as it depends on the internal policy of the institutions or the companies. Nevertheless, this channel serves a similar notion on an accountability mechanism, whereby the institutions receive a report of any misconduct of its officials both from the internal officials who notice the dereliction and from the outsider (societies or individuals).

One accountability element that cannot be separated with accountability mechanisms is the remedy. In addressing human rights infringements based on a development project, an effective remedy is essential.

Indonesian law guarantees compensation will be provided for people affected by development projects built for the sake of public interests. The government adopted the Law No 2/ 2012 on Land Procurement for Development for Public Interest. The category of public interests according to this law are, for example: roads, highways, tunnels, railway tracks, train stations and their facilities, dams, irrigation systems, drinking water facilities, sanitation, sewage systems, ports, airports, bus stations, and hospitals, etc. ${ }^{102}$ Article 36 stipulates that forms of compensation can be awarded in cash form, alternative land, resettlement, share ownership, or in other forms agreed upon by the parties.

Although Indonesia recognises compensation and remedies, several drawbacks persist including the problem of discrimination. ${ }^{103}$ Daniel Fitzpatrick, a

101 Permenpan-Menteri Pendayagunaan Aparatur Negara (Ministry of Administrative), currently the name of the ministry has been changed into the Ministry of Administrative and Bureaucratic Reform. This ministry is in charge of regulating the public servants at national level; therefore, the ministry is responsible for enacting the guidelines for all state apparatus to provide the best services to the people.

102 Law No 2/2012 on Pengadaan Tanah Bagi Pembangunan Untuk Kepentingan Umum (Land Procurement for Development in the Public Interest) art. 10.

103 Daniel Fitzpatrick, "Beyond Dualism: Land Acquisition in Indonesia" in Tim Lindsey, ed, Indonesia: Law and Society, 2nd edition, (Sydney: The Federation Press, 2008) 224 at 232-233. See also the report conducted by the Human Rights Watch stating that the compensation available is inadequate due to several reasons such as the lack of consultation; low 
socio-legal scholar, discovered the discrimination, particularly in the differences in compensation directed at owners, land occupiers who have and do not have certificates of title to their lands, and groups who were vulnerable to the state coercion. ${ }^{104}$ The remedy and compensation scheme is even more complicated in the existence of so-called "unlawful occupancy"105 and "illegal settlements."106

The problems of compensation can be seen from the evictions based on the development project of the flood prevention system in Jakarta. Many of the evicted people had lived in the informal settlements for years without any objection from public entities; they also received government public services, such as electricity and, to a certain extent, also paid taxes. In particular cases, they are allowed to live in the area where they had the tacit agreement with the authorisation of state-owned companies. For example in the Duri Tambora Jakarta, the community had a deal with the PT KAI, the Indonesian railroad company. ${ }^{107}$ They built their houses permanently, and then in some cases, the owners sold their houses or leased them to immigrants. In this regard, problems may arise, such as who will receive the remedy or compensation if any violation, such as eviction or any disaster occurs. The Jakarta government has stated that no compensation is available for those who have built their houses in the "nonsettlement" location. However, the government provides the eviction victims with walk-up rental houses. In some cases, the compensation is inadequate, therefore the affected people cannot use the compensation to look for another alternative.

This section has identified that accountability mechanisms exist in Indonesia. People affected by development can employ most of the available mechanisms, although the mechanisms that they can use will also depend on the nature of their case as well as the parties involved. The citizens are aware of these procedures and continuously employ the mechanisms to defend their rights. This fact is shown in several cases on evictions based on development projects that are brought before the courts. ${ }^{108}$ The cases mostly went to all level of mechanisms, for

compensation compared with the real loss, the compensation is reduced by officials, etc. see details at HRW, supra note 48.

104 Fitzpatrick, supra note 103.

105 This term refers to those who occupy land long before the enactment of the Agrarian Law in 1960, as a result of traditional "adat" means in acquiring land that is rampant in Indonesia. In addition, these occupations also occurred due to the massive changes in urban areas and the former colonial plantation. Although the agrarian law provides that adats long-term possession could still be governed as ownership rights, some of occupants had been evicted despite that they had paid land taxes for ages. See in Daniel Fitzpatrick note 103, at. 238.

106 Illegal settlements refer to people living in the areas that are not directed as housing complexes or settlements, these includes parks, river bank, railway track, national forests, etc.

107 United Nations General Assembly (UNGA), Report of the Special Rapporteur on adequate housing as a component of the right to an adequate standard of living, and on the right to nondiscrimination in this context, Raquel Rolnik, UN Doc. A/HRC/25/54/Add.1, 26 December 2013 , at 16 .

108 In addition to the cases mentioned in this article, there are also several other court cases related to evictions based on development project both in Jakarta or in other cities. For example, in 
example, from the court of first instance to the Supreme Court. Citizens usually claim against the government either with representatives (lawyers or NGOs) or by themselves. The success of such claims cannot be predicted as they depend on the evidence presented before the mechanisms and on judges' interpretation of applicable law and cases.

The available accountability mechanisms are limited only to those that are available at the domestic level. Indonesians cannot use mechanisms available at the international level to claim the infringement of economic, social and cultural (ESC) rights, i.e. individual complaint procedures before the Committee on Economic, Social and Cultural Rights. Such access is only applicable if the Indonesian government ratified the Optional Protocol II of the ICESCR. At this moment, the violations on the ESC rights can only be brought before national mechanisms.

Although relevant mechanisms are available and guaranteed based on national laws and can be accessed in non-discriminatory basis, the effectiveness of these mechanisms in handling cases with regard to development projects still needs to be thoroughly investigated.

\section{CONCLUSION}

Development projects can bring two sides of consequences, either positive or negative effects. The latter is unavoidable. States should adopt measures to the best of their disposal to reduce adverse impacts, particularly those affecting the most impoverished groups in the society. As discussed previously, there is a relationship between development and human rights, as well as between poverty and human rights. However, international human rights norms do not recognise freedom from poverty. Freedom of poverty relates to the provisions of the right to an adequate standard of living that is also considered as subsistence rights or basic rights. The fulfilment of the essential rights will influence other human rights. As development may also lead to poverty which can hinder human freedoms and human dignity, poverty eradication should become the first item on the agenda of every state.

Indonesia, as a developing country, also experiences significant development projects and their effects on society. Several measures have been adopted to address poverty, some of which have been very successful in reducing the poverty level. Poverty is experienced more by urban communities who live in slums. With regard to urban poverty, several measures such as urban settlement upgrading have also been implemented. In targeting zero slums in 2009, the government adopted schemes including the provision of mortgage facilities for low-incomes,

relation to the construction of the new Jogjakarta international airport, at least three cases have been brought before the Yogyakarta administrative court claiming the illegality of the projects and the human rights infringements that were caused by the construction. 
integration of housing with social-net support facilities, community-based in-situ slum upgrading programs, and the construction of affordable houses.

As a result of the plan to build a flood prevention system, local governments, for example Jakarta and Surabaya, have evicted people from riverbank slums. Instead of providing community-based in-situ slum upgrade programmes, the government has provided rented public housing to only the registered residents. The idea of providing such housing was to alleviate poverty, eradicate slums, and increase housing adequacy for inhabitants. However, it turned out that the slums' inhabitants were still living in poverty, at the same time they lost their job and had to adapt to a new environment. In addition, the time limit to be able to stay in the public housing makes the condition worst. Therefore, the resettlement into rented public housing cannot be considered as an effort to alleviate poverty. This strategy might lead to more severe cases of poverty if the governments do not adopt further strategies by employing the HRBA.

One of the elements of the HRBA is the availability of accountability mechanisms that can be used by people in seeking redress and remedies if a development project negatively affects their life. Domestically, the Indonesian legal system provides several accountability mechanisms, ranging from administrative to legal mechanisms. The latter includes both judicial and quasijudicial mechanisms. There is a need to investigate the effectiveness of these accountability mechanisms in dealing with development-based effects.

It has been noticed that the current development programmes have been much in favour of the poor and target poverty alleviation. The governments are not the only parties involved in achieving the targets; many other parties are also involved, including the communities themselves. In this regard, the communities should be educated to be fully aware of the responsible institutions that can be held accountable for their conducts. On the other hand, the governments also have to ensure that all parties are accountable to the people and are willing to be accountable.

Acknowledgement - The author wishes to express her sincere gratitude to the Indonesia Endowment Fund for Education (LPDP) for enabling her to pursue a doctoral study in the Faculty of Law University of Groningen the Netherlands. The author sincerely thanks to: (1) the Committee of the 3rd Annual Conference (2018), "Narrating Human Rights: Issues of Migration, Discrimination, and Protection of Human Rights in Southeast Asia"; (2) The Horizon2020 project 'Prevention and Resilience for Urban Vulnerabilities (PRUV), University of Groningen, for their generosity in providing a travel grant to presenting my article in the conference as well as to conducting a research visit in Indonesia. 


\section{BIBLIOGRAPHY}

\section{Legislation}

The 1945 Constitution of the Republic of Indonesia

Law No. 39/1999 on Hak Asasi Manusia (Human Rights Law).

Law No. $17 / 2007$ on Pembangunan Menengah Jangka Panjang Nasional (the National Long-Term Development Plan) 2005-2025.

Law No. 28/1999 on Penyelenggaraan Negara yang Bersih dan Bebas dari Korupsi, Kolusi dan Nepotisme (Clean Governance and Corruption, Collusions and Nepotism Free).

Law No 48/2009 on Kekuasaan Kehakiman (Judicial Power).

Law 51/2009 on Perubahan kedua Undang Undang No. 5/1986 tentang Pengadilan Tata Usaha Negara (the $2^{\text {nd }}$ Amendment of Law 5/1986 on Administrative Court).

Law No 2/2012 on Pengadaan Tanah Bagi Pembangunan Untuk Kepentingan Umum (Land Procurement for Development of Public Interest).

Regulation of the Menteri Pendayagunaan Aparatur Negara (Ministry of Administrative) No. 13/2009 on Pedoman Peningkatan Kualitas Pelayanan Publik dengan Partisipasi Masyarakat (Guidelines on the Improvement of Quality in Service Delivery with Public Participation).

Local Regulation of Kota Surabaya No. 2/2010 on Pemakaian Rumah Susun (The Usage of Multi-storey Housing).

Mayor Regulation of Yogyakarta No. 44/2009 on Pengelolaan Rumah Susun Sederhana Sewa Milik Pemerintah Kota Yogyakarta (the Management of Rented Multi-storey Housing owned by the Jogjakarta Municipality).

\section{Jurisprudence}

Galuh Radiah et al. v. Gubernur Provinsi Daerah Khusus Ibu Kota Jakarta (Jakarta Administrative Court, 25 April 2016, judgment) 59/G/2016/PTUNJKT online: Mahkamah Agung Republik Indonesia - MARI (The Indonesian Supreme

<https://putusan.mahkamahagung.go.id/putusan/c65c8cd899a7de940c022368c 0bc965> 
Unsafe River Bank Houses? A Context of Human Rights Issues on Freedom from Poverty, Development Programmes, and Accountability Mechanisms in Indonesia

Gubernur Provinsi Daerah Khusus Ibu Kota Jakarta v. Galuh Radiani et al (MARI, 23 August 2016, judgment) 267 K/TUN/2016, online: MARI https://putusan.mahkamahagung.go.id/putusan/c65c8cd899a7de940c022368c0 $\underline{\mathrm{bc} 965}$

\section{International Materials}

Universal Declaration on Human Rights (adopted on 10 December 1948) UN Doc: GA Res. 217 A (III) online: OHCHR <https://www.ohchr.org/EN/UDHR/Documents/UDHR_Translations/eng.pdf>.

International Covenant on Economic, Social and Cultural Rights (adopted on 16 December 1966, entered into force 3 January 1976) 993 UNTS (ICESCR).

UN Committee on Economic, Social and Cultural Rights (CESCR), General Comment No. 4: The Right to Adequate Housing (Art. 11 (1) of the Covenant), 13 December 1991, E/1992/23.

The Second Optional Protocol on Individual Complaints (10 December 2008) UN. Doc. A/RES/63/117, online: OHCHR <http://www.ohchr.org/Documents/HRBodies/CESCR/OProtocol_en.pdf>.

Vienna Declaration and Programme of Action, adopted by the World Conference on Human Rights on 25 June 1993, UN Doc: A/CONF.157/23.

United Nations Economic and Social Council (ESC), Report of the Independent Expert on Human rights and Extreme Poverty Arjun Sengupta, UN Doc: E/CN.4/2006/43; 2 March 2006.

United Nations General Assembly, the Basic Principles and Guidelines on Development-Based Evictions and Displacement, UN Doc A/HRC/4/18 (5 February 2007) <https://www.ohchr.org/Documents/Issues/Housing/Guidelines_en.pdf>.

United Nations General Assembly (UNGA), Report of the Special Rapporteur on adequate housing as a component of the right to an adequate standard of living, and on the right to non-discrimination in this context, Raquel Rolnik, UN Doc. A/HRC/25/54/Add.1, 26 December 2013.

\section{Books, Periodicals and Newspapers}

"Fewer, but still with us, The world has made great progress in eradicating extreme poverty", The Economist (30 March 2017) online: The Economist <www.theeconomist.com>. 
Alston, Philip. "Ships Passing in the Night: The Current State of the Human Rights and Development Debate seen through the Lens of the Millennium Development Goals” (2005) 27:3 Hum Rights Q 755, online: <http://muse.jhu.edu/content/crossref/journals/human_rights_quarterly/v027/27. 3alston.htm>

Badan Perencanan Pembangunan Nasional (BAPPENAS), Badan Pusat Statistik (BPS) and United Nations Population Fund (UNFPA), Proyeksi Penduduk Indonesia (Indonesia Population Projection) 2010-2035 (Jakarta, Badan Pusat Statistik, 2013) online: BAPPENAS <https://www.bappenas.go.id/files/5413/9148/4109/Proyeksi_Penduduk_Indone sia_2010-2035.pdf>.

Badan Pusat Statistik, Dasar-dasar Analisis Kemiskinan (Jakarta, Indonesian Statistic Agency and World Bank Institute, Jakarta, 2002).

Belasminus, Robertus. "Warga Kampung Pulo yang Direlokasi ke Rusun Kesulitan Bayar Sewa”, Kompas (31 March 2016) online: Kompas <https://megapolitan.kompas.com>.

Bovens, Mark. "Analysing and Assessing Accountability: A Conceptual Framework" (2007) 13:4 Eur Law J 447, online: <http://doi.wiley.com/10.1111/j.1468-0386.2007.00378.x>.

- "Two concepts of accountability: Accountability as a virtue and as a Mechanism” (2010) 33:5 West Eur Polit 946.

Budiardjo, Miriam. Menggapai kedaulatan Untuk Rakyat (Bandung: Mizan, 1998).

Krina P., Dra. Loina Lalolo. Indikator \& Alat Ukur Prinsip Akuntabilitas, Transparansi \& Partisipasi, online: Bakti Digital Library <https://baktilibrary.omeka.net/items/show/83>.

Campbell, Tom. " Poverty as a Violation of Human Rights: Inhumanity or Injustice?"in Thomas Pogge, ed, Free from Poverty as a Human Right who owes what to very poor? (Oxford: UNESCO and Oxford University Press, 2007

Chong, Daniel P L. "NGOs and Freedom from Poverty" in Free from Poverty NGOs Hum Rights Prax (Pensylvania: Univeristy of Pensylvania Press, 2010) 1.

Das, Ashok. "A City of Two Tales: Shelter and Migrants Surabaya" (2017) 8:1 Environtment Urban Asia 1. 
Unsafe River Bank Houses? A Context of Human Rights Issues on Freedom from Poverty, Development Programmes, and Accountability Mechanisms in Indonesia

Day, Patricia and Rudolf Klein, Accountabilities: Five Public Services (London: Tavistock Publications, 1987).

Direktorat Jenderal Cipta Karya, Rusunawa: Komitmen Bersama Penanganan Pemukiman Kumuh, Kementerian Pekerjaan Umum (Jakarta, 2012) 21-22, online: Dirjen Cipta Karya <http://ciptakarya.pu.go.id/bangkim/old_file/v2/download/ebook/Buku_Rusun awa_2012.pdf?iframe $=$ true\&width $=1400 \&$ height $=650$. $>$.

Donald, Alice \& Elizabeth Mottershaw. Poverty, Inequality and Human Rights: Do Human Rights Make a Difference? (2009).

Doz Costa, Fernanda. "Poverty and Human Rights: From Rhetoric to Legal Obligations - A Critical Account of Conceptual Framework" (2008) 81:9 Sur Int J Hum Rights 81.

Eckardt, Sebastian. "Political Accountability, Fiscal Conditions and Local Government Perfomance-Cross-sectional Evidence from Indonesia" (2008) 28:1 Public Adm Dev 1.

Fitzpatrick, Daniel, "Beyond Dualism: Land Acquisition in Indonesia" in Tim Lindsey, ed, Indonesia: Law and Society, 2nd edition, (Sydney: The Federation Press, 2008) 224.

Fellix Januardy, Alldo et al. Mereka yang Terasing: Laporan Pemenuhan Hak atas Perumahan yang Layak bagi Korban Penggusuran Paksa Jakarta yang Menghuni Rumah Susun (Jakarta: Lembaga Bantuan Hukum Jakarta, 2016).

Fellix Januardy, Alldo, Julio Castor Achmadi \& Cindy Iqbalini Fortuna. Seperti Puing: Laporan Penggusuran Paksa di Wilayah DKI Jakarta Tahun 2016 (Jakarta, 2017).

Hearne, Rory \& Padraic Kenna. "Using the Human Rights Based Approach" to Tackle Housing Deprivation in an Irish Urban Housing Estate" (2014) 6:1 J Hum Rights Pract 1.

Hirschl, Ran. "" Negative " Rights vs . " Positive " Entitlements : A Comparative Study of Judicial Interpretations of Rights in an Emerging Neo-Liberal Economic Order” (2000) 22:4 Hum Rights Q 1060, online: $<$ http://www.jstor.org/stable/4489315 >.

Human Rights Watch (HRW), Condemned Communities Forced Evictions, Vol 18 No. 10C (Jakarta: HRW, 2006) online: HRW < Human Rights Watch, "Condemned Communities Forced Evictions>. 
Ikawati, Nuri et al, Penggusuran dan Reproduksi Kemiskinan Kota: Studi Kasus di Empat Rusunawa Jakarta (Jakarta, 2017) 22-25.

"Indonesia to strive for poverty rate below 10 percent", Jakarta Post (4 January 2018) online: The Jakarta Post < http://www.thejakartapost.com>.

Jones, Paul. "Formalizing the informal: Understanding the position of informal settlements and slums in sustainable urbanization policies and strategies in Bandung, Indonesia" (2017) 9 Sustainability.

Jonsson, Urban. Human Rights Approach to Development Programming (UNICEF, 2003).

Kusumawati, Erna Dyah. "Between Public and Communal Interests: a Legality Issue of Forced Evictions Occurring in Jakarta" (2018) 8:1 Indones Law Rev 87.

Kusumawati, Erna Dyah, The Recurring Dream of Affordable Housing in Indonesia: A Human Rights Perspective in Michel Vols \& Sidoli, J. (eds.), People and Buildings: Comparative Housing Law. Studies in Housing law Vol. 2 (The Hague: Eleven International Publisher) 105-140;

Kusumawati, Erna Dyah, De wolf, Antenor H. \& Brus, M.M.T.A, "Access to Public Housing for Outsiders; a Practice of Indirect Discrimination in Decentralised Indonesia" (Forthcoming) APJHRL.

Macdonald, Kevin Alan David, "Indigenous peoples and development goals: A global snapshot" in Gillette H Hall \& Harry Anthony Patrinos, eds, Indigenous Peoples, Poverty, and Development (Cambridge: Cambridge University Press, 2012) 17.

McNeill, Desmond \& Asuncion Lera St Clair. "Poverty, Human Rights, and Global Justice: The Response-Ability of Multilateral Organizations” (2011) 8:1 Globalizations 97, online: <http://www.tandfonline.com/doi/abs/10.1080/14747731.2011.544212〉.

OHCHR, Human Rights Dimension of Poverty, online: OHCHR <https://www.ohchr.org/EN/Issues/Poverty/DimensionOfPoverty/Pages/Index.a spx>.

OHCHR, Frequently Asked Questions on a Human Rights-Based Approach to Development Cooperation, HR/PUB/06/8, 2006, at 16-18, online: OHCHR $<$ http:/www.ohchr.org/Documents/Publications/FAQen.pdf>.

Ploeg, Lidewij van der \& Frank Vanclay. "A human rights based approach to 
Unsafe River Bank Houses? A Context of Human Rights Issues on Freedom from Poverty, Development Programmes, and Accountability Mechanisms in Indonesia

project induced displacement and resettlement" (2017) 35:1 Impact Assess Proj Apprais 34, online: <https://www.tandfonline.com/doi/full/10.1080/14615517.2016.1271538>.

Pogge, Thomas. "Severe Poverty as a Human Rights Violation" in Thomas Pogge, ed, Free from Poverty as a Human Right who owes what to very poor? (Oxford: UNESCO and Oxford University Press, 2007) 11.

Potts, Hellen. "Accountability and the Right to Highest Attainable Standard of Health" in Paul Hunt and Tony Gray, eds, Maternal Morality, Human Rights and Accountability (New York: Routledge, 2013) 121.

Potts, Helen. Accountability and the Right to the Highest Attainable Standard of Health. (Essex, 2007).

R Osmani, Siddiq. "The Human Rights-based Approach to Development in the Era of Globalization" in OHCHR, ed, Realiz right to Dev Essays Commem 25 Years United Nations Declar Right to Dev (New York: United Nations, 2013) 117.

Reerink, Gustaaf \& Jean Louis van Gelder. "Land titling, perceived tenure security, and housing consolidation in the kampongs of Bandung, Indonesia" (2010) 34:1 Habitat Int <http://dx.doi.org/10.1016/j.habitatint.2009.07.002>.

Sen, Amartya. "Concepts of Poverty" in Poverty Famines An Essay Entitlement (Oxford: Oxford University Press, 1983) 1.

Stapenhurst, Rick and Mitchell O'Brien, Accountability in Governance, online: World Bank Publication 〈http://siteresources.worldbank.org>.

Suryahadi, Asep, Gracia Hadiwidjaja \& Sudarno Sumarto. "Economic Growth and Poverty Reduction in Indonesia Before and After the Asian Financial Crisis” (2012) 48:2 Bull Indones Econ Stud 209.

Sutari, Tiara. "Warga Rusun Akui Tunggak Sewa Karena Kesulitan Ekonomi", CNN Indonesia (6 September 2017) online: CNN Indonesia <https://www.cnnindonesia.com>.

Terminski, Bogumil. Development-Induces Displacement and Resettlement: Causes, Consequences and Socio Legal Context (Stuttgart: Ibidem, 2015).

The Office of the United Nations High Commissioner for Human Rights (OHCHR), Human Rights and Poverty Reduction: A Conceptual Framework, (Geneva, New York: United Nations, 2004) online: OHCHR < 
https://www.ohchr.org/Documents/Publications/PovertyReductionen.pdf>.

Tunas, Devisari \& Andrea Peresthu. "The self-help housing in Indonesia: The only option for the poor?" (2010) 34:3 Habitat Int 315, online: <http://dx.doi.org/10.1016/j.habitatint.2009.11.007>.

Vandenhole, Wouter \& Paul Gready. "Failures and Successes of Human RightsBased Approaches to Development: Towards a Change Perspective" (2014) 32:4 Nord J Hum Rights 291, online: <http://www.tandfonline.com/doi/abs/10.1080/18918131.2015.957458>.

Voorst, Roanne Van. "Applying the risk society thesis within the context of flood risk and poverty in Jakarta, Indonesia" (2015) 17:3-4 Heal Risk Soc 246.

Sen, Amartya. "Concepts of Poverty" in Poverty Famines An Essay Entitlement (Oxford: Oxford University Press, 1983).

Shue, Henry. Basic Rights: Subsistence, Affluence, and U.S. Foreign Policy, $2^{\text {nd }}$ ed (Princeton: Princeton University Press, 1996).

Suryahadi, Asep et al. Review of Government's Poverty Reduction Strategies, Policies, and Programs in Indonesia (Jakarta, 2010).

United Nations Development Program (UNDP), Human Development Report 2000: Human Rights and Human Development, (New York: Oxford University Press \& UNDP, 2000).

W. Soemarwi, Vera, Handika Febrian \& Kristian Feran, Politik Hukum Rusunawa dalam Penggusuran Paksa Warga Bukit Duri: Studi Kasus Rusunawa Rawa Bebek (Jakarta: Yayasan Ciliwung Merdeka, 2017).

Wetterberg, Anna, Jana C. Hertz, \& Derick W. Brinkerhoff," Social Accountability in Frontline Service Delivery: Citizen Empowerment and State Response in Four Indonesian Districts" in the International Development Group Working Paper Series (New York: the RTI International, 2015).

\section{General Websites}

The UN Habitat website <http://urbandata.unhabitat.org/exploredata/?countries=ID\&indicators=slum_proportion_living_urban,population,urb an_population_cities>. 
Unsafe River Bank Houses? A Context of Human Rights Issues on Freedom from Poverty, Development Programmes, and Accountability Mechanisms in Indonesia

Erna Dyah Kusumawati is a $\mathrm{PhD}$ candidate at the Department of Transboundary Legal Studies, Faculty of Law, University of Groningen, Oude Kijk in 't Jatstraat 59, 9712 EK Groningen, The Netherlands. Teaching staff at the International Law Department, Faculty of Law, University Sebelas Maret Surakarta, Jalan Ir. Sutami No. 36 A. Surakarta 57126, Indonesia. Her doctoral study is funded by the Indonesian Endowment Fund for Education (LPDP) of the Ministry of Finance of the Republic of Indonesia. Her research focuses on the implementation of the right to housing in Indonesia. Email: e.dyah.kusumawati@rug.nl; erna.d.kusumawati@staff.uns.ac.id 